\title{
SAFB wt Allele
}

National Cancer Institute

\section{Source}

National Cancer Institute. SAFB wt Allele. NCI Thesaurus. Code C52104.

Human SAFB wild-type allele is located within 19p13.3-p13.2 and is approximately $45 \mathrm{~kb}$ in length. This allele, which encodes scaffold attachment factor B protein, is involved in transcriptional regulation. 